\title{
A Model of Vignette for Motor Vehicles in the Czech Republic
}

\author{
Břetislav Andrlík ${ }^{1}$, Lucie Zborovská \\ 1 Mendel University in Brno \\ Faculty of Business and Economics, Department of Accounting and Taxes \\ Zemědělská 1, 61300 Brno, Czech Republic \\ E-mail: bretislav.andrlik@mendelu.cz \\ 2 Mendel University in Brno \\ Faculty of Business and Economics, Department of Accounting and Taxes \\ Zemědělská 1, 61300 Brno, Czech Republic \\ E-mail: xzborov@mendelu.cz
}

\begin{abstract}
This article examines the fees applied to vehicles of the maximum weight of $3.5 t$ based on time. It focuses on the analysis of the current application of timebased fees in individual countries of the EU. This analysis is carried out as a supporting tool serving the design models available in the Czech Republic. The goal of the contribution is designing a new model of time-based pricing of road motor vehicles in the territory of the Czech Republic. The contribution also includes the analysis of legal standards regulating the issue in the Czech Republic and in the EU countries; the analysis only deals with EU legal standards that directly address the area. The outcome of the contribution is a constructed model of a time-based fee, based on pre-defined assumptions, which were determined by needs ensuing from the current conditions that affect the operation of chargeable passenger cars and light commercial vehicles. In conclusion, a comparison of receipts from the current system of time-based fees with receipts resulting from the proposed model of timebased fees for the Czech Republic is made. The results shown in Table 6 show that the application of the newly defined time-based fee model in the Czech Republic leads to increased public budget revenues by $3.14 \%$, ie by CZK 149.262 million in absolute terms.
\end{abstract}

Keywords: fee, vignette, Czech Republic, motor vehicle, European Union

JEL codes: $H 2 O, H 23$

\section{Introduction}

Road passenger and freight transport is one of the key sectors of modern market economies and construction or renewal of transport infrastructure is necessary for the development of economy as a whole. The first efforts to determine uniform principles of transport policy were embedded in the Treaties of Rome, namely the Treaty Establishing the European Economic Community (1957), which addressed common rules for international transport, free access to transport services for all member states and prohibition of discrimination of certain transport sectors. The political representations of individual EU member states strive to raise sufficient 
funds to improve the quality of the transport infrastructure and to cover the negative externalities of environmental and public health impacts. A negative externality originates in the event that a part of the costs generated in connection with motor traffic is transferred to the society, for instance in the form of environmental damage; then the society bears a part of costs of another person's consumption. Such externalities include the risk of traffic accidents and mortality due to the overloaded infrastructure, noise and pollution of the environment (Cnossen, 2005 and Andrlík, 2012, 2014). The costs of negative externalities should be internalized by charging vehicles for the use of infrastructure. The elimination of negative impacts attributed to transport, which include greenhouse gas emissions and other pollutants, but also noise or infrastructure damage, is one of the key points raised in the White Paper (2011), the European Union's strategic document focused on transport (published in 2001, final version in 2011). The entities participating in transport should use the infrastructure in better ways and mitigate the negative impacts on the environment and the society. The correct price setting and application of principles "user pays" and "polluter pays", stipulated by Directive 2006/38/EC of the European Parliament and of the Council are the ways to make the infrastructure users realize what impacts their decisions have on their surroundings. The internalization of negative externalities through adequate fees and taxes can be an appropriate means of enforcing these principles. It includes taxes on fuel as a source of greenhouse gases and pollutant emissions, as well as taxes and fees for the infrastructure use and other related externalities (Andrlík, Mísařová, Vrtalová, 2014). Whereas fuel taxes apply to all vehicles, taxes and fees for the infrastructure use are firmly set only for heavy goods vehicles in the EU at present.

The EU member states aim to achieve the above goals through tax policy instruments, where the main measures are the collection of a fee based on time (vignette) or a fee based on the distance (toll) for the use of selected sections of the infrastructure in the country concerned. The tradition of paying a toll dates back to the remote past; the toll was imposed on roads, bridges or ferries. Everyone who wanted to use such sections had to pay the price which depended on the value of the carried goods. The fee for the use of infrastructure based on the distance depends on the number of kilometers traveled by a road motor vehicle along the charged sections of infrastructure in the EU country concerned. The issue of fees based on distance traveled is explored in more detail by Andrlík, Zborovská (2019). The fee based on the distance traveled may be paid physically at a toll gate or electronically through toll gates or using technologies based e.g. on the GPS.

This article deals with the time-based fee in the form of a vignette. The goal of the contribution is to design a new model of time-based pricing of road motor vehicles in the territory of the Czech Republic. Time units are used for the determination of the amount of the fee. Most of the EU countries use the intervals of one week, one month, and one year. This form of time-based fee is mostly used for passenger cars and light commercial vehicles (N1 category). Two forms of vignettes are currently used in the European Union: paper and electronic. 


\section{Methodology}

The achievement of the pre-set goal is based on the study of a number of specialized texts, including legal regulations related to the topic both in the Czech Republic and the European Union. The most important data are numerical characteristics available in official statistics prepared by public authorities in the Czech Republic. All the sources used in this article are listed in the bibliography section below. The underlying research is based on the methods of description and analysis, in particular concerning the section dealing with vignettes in the Czech Republic and EU countries.

The construction of the model uses numerical methods for the formulation of subprocesses leading to the design of the model of time-based pricing of road motor traffic in the Czech Republic. This includes namely the determination of shares of the different types of vehicles in the total number of vehicles traveling along charged sections of the infrastructure. Such shares are used for the determination of vignette prices for the new suggested category, i.e. motorcycles. The expected receipts from the sale of vignettes are subsequently calculated for all included categories and are compared with the current amount of receipts from vignettes.

\section{Vignettes in the Czech Republic and EU Countries}

The determination of charges on light vehicles is set out in the Communication from the Commission $\operatorname{COM(2012)~} 199$ on the application of national road infrastructure charges levied on light private vehicles. As stated in the document, the rules of collection of charges for light private vehicles are based on the Treaty on the Functioning of the European Union (2012) and due to the non-existence of a European regulation, the member states are entitled to apply virtually any system of pricing the use of road infrastructure. Such system, however, has to observe two basic principles that are embedded in the Treaty on the Functioning of the European Union (2012). These are the principles of non-discrimination and proportionality in connection with citizenship.

Vignettes were introduced in the Czech Republic in 1995 by Act No. 134/1994 Coll., changing and amending Act No. 135/1961 Coll., Road Act. Until the year 2006, it was compulsory to buy the vignette for all categories of road motor vehicles (except motorcycles). For the following three years, this obligation applied to vehicles with the maximum permitted weight of $12 \mathrm{t}$; since the year 2010, the vignettes apply only to vehicles with the maximum permitted weight of $3.5 \mathrm{t}$ (SFDI, 2018). The use of vignettes is regulated by Act No. 13/1997 Coll., Road Act, as amended by subsequent regulations. Section 20 (2) Act No. 13/1997 Coll., as amended (hereinafter referred to as "Act No. 13/1997") stipulates two methods of pricing the selected roads. If the decisive factors are the vehicle type and distance traveled, a toll is paid. If the fee is based on a time period, it is in the form of a vignette. One and the same road motor vehicle cannot be imposed both the toll payment and the vignette purchase. 
Vignettes are compulsory for all vehicles with at least four wheels and the maximum permitted weight of $3.5 \mathrm{t}$ driving along roads that are subject to charges. Section 2 of Government Regulation No. 240/2014 Coll., on the amount of time-based fees, toll rates, toll discounts, and the procedure for applying toll discounts (hereinafter referred to as "Regulation No. 240/2014) stipulates that the time-based fee may be paid for a calendar year, a month or for 10 calendar days. The present system of paper vignettes will be replaced with electronic vignettes (MD ČR, 2019), which is supposed to save several millions CZK annually and at the same time to increase the receipts thanks to the camera systems utilizing the existing toll gates that have been built on charged roads. The new system should be introduced in the year 2021.

At present, the Czech Republic uses the microwave toll system for vehicles over $3.5 \mathrm{t}$, similarly to a number of other EU countries. Toll rates are determined according to the distance traveled, EURO emission standard, number of axles, type of road, and time of day under Government Regulation No. 240/2014 Coll. (2019). The current system of toll collection uses toll gates which record each passing vehicle that is subject to the fee on the charged section of the road. The Czech Republic plans to introduce a satellite system of toll collection that is currently used in Germany and Slovakia.

There are exemptions from the payment of fees for road motor vehicles which carry severely handicapped citizens and other road motor vehicles listed in Section 20a Act No. 13/1997. It should be added that the obligation to have a vignette or pay a toll does not apply to motorcycles in the Czech Republic.

Environmentally friendly vehicles are not exempt from the duty to pay the fee at present. The issues of benefits for environmentally friendly vehicles are examined by Andrlík (2012, 2014) and Andrlík, Péteriová (2019). As early as in 2008, the Opinion $\operatorname{COM}(2008) 435$ defined the strategy for the internalization of external costs of transport. It states that transport generates negative externalities that involve costs to society and economy. These are for instance delays as a result of congestion, health problems caused by noise and air pollution or the effects of $\mathrm{CO}_{2}$ emissions on climate change. The volumes of such negative externalities should be reflected in the correct and fair prices determined according to the "polluter pays" and "user pays" principles. The goal is to make transport users aware of the generated external costs and encourage them to change their behavior in order to reduce those negative externalities. The main economic instruments for the internalization of external costs of transport are taxes, road charges, and emission permits. The instrument of internalization should be adapted to the characteristics of the externality (place, time and impact). The levels of economic instruments should be such so as to avoid market disruptions. The Opinion mentions that considerable funds must be raised to make transport sustainable, and be used for research, innovation, investment in more environmentally friendly infrastructure, development of public transport, etc. Therefore, revenues from the economic 
instruments should be allocated to the transport sector and used for the reduction of external costs.

Table 1 lists the countries which use the EURO emission standard as one of the principal components in setting rates of non-tax charges related to road motor vehicle operation. The emission standards primarily aim at the reduction of the content of nitrogen oxide, hydrocarbons, carbon monoxide and particulate matter in emissions from petrol and diesel engines. Methane-free hydrocarbons and soot are monitored in heavy goods vehicles. However, the standards do not address the amount of carbon dioxide $\left(\mathrm{CO}_{2}\right)$, which significantly contributes to the greenhouse effect and, unlike carbon monoxide (CO), is not toxic (Sajdl, 2019). The individual EURO emission standards set the maximum values of harmful substances in exhaust fumes ( $\mathrm{CO}, \mathrm{HC}, \mathrm{NO}_{\mathrm{x}}$ and $\left.\mathrm{PM}\right)$ and thus substitute the ecological element.

Table 1 EU Member States Considering EURO Standards in the Pricing of Road Motor Traffic

\begin{tabular}{|c|c|c|c|}
\hline & Country & Type of charge & Vehicle category \\
\hline 1 & Belgium & toll & $>12 \mathrm{t}$ \\
\hline 2 & Bulgaria & vignettes & $>3.5 \mathrm{t}$ \\
\hline 3 & Czech Republic & toll & $>3.5 \mathrm{t}$ \\
\hline 4 & Denmark & toll & $>12 \mathrm{t}$ \\
\hline 5 & Estonia & toll & $>12 \mathrm{t}$ \\
\hline 6 & Lithuania & vignettes & $\begin{array}{r}\text { buses and coaches of M2 and M3 } \\
\text { category, heavy duty vehicles and } \\
\text { their combinations of categories N1- } \\
\text { N3 and special road vehicles in M2, } \\
\text { M3, and N1-N3 categories. }\end{array}$ \\
\hline 7 & Latvia & toll & $>3.5 \mathrm{t}$ \\
\hline 8 & Luxembourg & toll & $>12 \mathrm{t}$ \\
\hline 9 & Hungary & toll & $>3.5 \mathrm{t}$ \\
\hline 10 & Germany & toll & $>7.5 \mathrm{t}$ \\
\hline 11 & The Netherlands & toll & $>12 \mathrm{t}$ \\
\hline 12 & Poland & toll & $>3.5 \mathrm{t}$ \\
\hline 13 & Austria & toll & $>3.5 \mathrm{t}$ \\
\hline 14 & Slovak Republic & toll & $>3.5 \mathrm{t}$ \\
\hline 15 & Slovenia & toll & $>3.5 \mathrm{t}$ \\
\hline 16 & Sweden & toll & $>12 t$ \\
\hline
\end{tabular}

Source: Authors' own work based on ACEA (2019) 
It is apparent from data in Table 1 that 16 out of the 28 member states of the EU try to combat negative externalities caused by motor vehicles with weight exceeding 3.5 t. 15 out of the 16 countries do not address environmental issues for vehicles of up to $3.5 \mathrm{t}$. According to ACEA (2019), an environmental element in the form of EURO standard is only applied by Lithuania, which imposes vignettes, but this measure is limited to buses and coaches of M2 category, heavy duty vehicles and their N1 category combinations and special vehicles in N1 and M2 categories. The above does not apply to motorcycles and passenger cars.

All countries listed in Table 1 (including Lithuania) differentiate the rates of vignettes or tolls on the basis of EURO standards only for vehicles over $3.5 \mathrm{t}$. In Bulgaria and Lithuania, the environmental element in the form of EURO standard is incorporated in the prices of vignettes; the other countries reflect it in the prices of tolls. In Belgium, the Czech Republic, Denmark, Lithuania, Luxembourg, Hungary, Germany, the Netherlands, Poland, Austria, Slovakia, Slovenia, and Sweden, the EURO standard is important in the process of setting rates for all vehicles subject to the charging. In Bulgaria, the EURO standard is used to determine the rate only for vehicles exceeding $3.5 \mathrm{t}$, in Estonia it is $12 \mathrm{t}$ and Latvia $3.5 \mathrm{t}$.

The Czech government approved an amendment to Act No. 13/1997 on 4 February 2019 , in which the introduction of electronic vignettes is encoded since 2021 . Then, the Czech Republic will become one of the countries that apply the system of electronic vignettes, which works on the principle of registration of the license plate number in a mobile application or on the Internet; payment at some distribution points will also be possible. The physical sale of vignettes, existing nowadays, will end upon the introduction of the electronic system. According to MD ČR (2019), almost 100 million CZK could be saved thanks to the electronic system compared with the current situation. Payments will be monitored by the customs administration and the police through stationary or mobile cameras. The system is used in Slovakia, Hungary, Austria, and pending in Germany. The process of vignette electronization in the Czech Republic will be implemented by the Austrian company ASFINAG, which has been administering electronic vignettes in Austria since their introduction in 2018.

As set out in Section 20 (4) Act No. 13/1997, funds obtained from time-based fees are an income of the State Fund of Transport Infrastructure (SFDI). Annex No. 2 of Decree No. 386/2017 Coll., amending Decree No. 306/2015 Coll., on the use of roads priced through a time-based fee, as amended by Decree No. 383/2016, mentions that vignettes must be used on 29 sections and approximately $968 \mathrm{~km}$ of motorways and expressways.

As mentioned above, the Czech Republic currently imposes vignettes for all road motor vehicles with at least four wheels and the maximum permitted weight of 3.5 $t$ passing along roads that are subject to charges. This duty does not apply to motorcycles, which are not subject to any other charges on operation, either. The 
prices of vignettes are set uniformly for all types of vehicles and are listed in Table 2.

Table 2 Vignette Prices in the Czech Republic in 2019

\begin{tabular}{lccc}
\hline & $\begin{array}{l}\mathbf{1 0} \text { days } \\
\text { (in CZK) }\end{array}$ & $\begin{array}{c}\mathbf{3 0} \text { days } \\
\text { (in CZK) }\end{array}$ & $\begin{array}{c}\mathbf{1} \text { year } \\
\text { (in CZK) }\end{array}$ \\
\hline \hline Vehicles up to 3.5 t & 310 & 440 & 1500 \\
\hline
\end{tabular}

Source: Government Regulation No. 240/2014 Coll

Only 17 countries of the European Union (Bulgaria, Czech Republic, France, Croatia, Ireland, Italy, Lithuania, Latvia, Hungary, Poland, Portugal, Austria, Romania, Greece, Slovak Republic, Slovenia, and Spain) set fees for the use of infrastructure by vehicles with the maximum permitted weight of up to $3.5 \mathrm{t} .8$ out of the 17 countries (Bulgaria, Czech Republic, Lithuania, Hungary, Austria, Romania, Slovakia, and Slovenia) apply a time-based fee in the form of a vignette. In Bulgaria, Romania and Lithuania, vignettes are the only form of road pricing. On the other hand, vignettes are compulsory for all vehicles except motorcycles in Bulgaria and Romania. Lithuania imposes the purchase of a vignette on vehicles of up to $3.5 \mathrm{t}$ as well as on vehicles weighing more than $3.5 \mathrm{t}$. However, in the case of vehicles of up to $3.5 \mathrm{t}$, this fee is only mandatory for M2 category buses and coaches, heavy duty vehicles and their combination in N1 category and special vehicles of categories N1 and M2. The duty does not apply to motorcycles and passenger cars in Lithuania. In vehicles over $3.5 \mathrm{t}$, the charges are imposed on buses and coaches of M3 category, heavy duty vehicles and their combinations of categories N2, N3 and special road vehicles in M3, N2 and N3 categories. The Czech Republic, Hungary, Austria, Slovakia, and Slovenia have introduced vignettes only for vehicles with the maximum permissible weight of $3.5 \mathrm{t}$. Motorcycles are also subject to vignette purchase in Hungary, Austria, and Slovenia. On the contrary, in the Czech Republic and the Slovak Republic (as well as in Bulgaria, Romania, and Lithuania), motorcycles are not required a vignette when traveling on charged roads (ACEA, 2019 and Andrlík, Ptáčková Mísařová, 2018). The amount of fee is contingent only on the duration of the vignette validity in the Czech Republic and Slovakia. In Bulgaria, Hungary, Austria, Romania, Slovenia, and Lithuania, the amount is determined on the basis of a unit of time, but also according to the vehicle category. Besides, the role of the EURO standard, which affects the amount paid for the vignette, is also decisive in Bulgaria (only for vehicles over $3.5 \mathrm{t}$ ) and Lithuania. 
Figure 1 Prices of Annual Vignette for Passenger Cars in EUR, year 2019

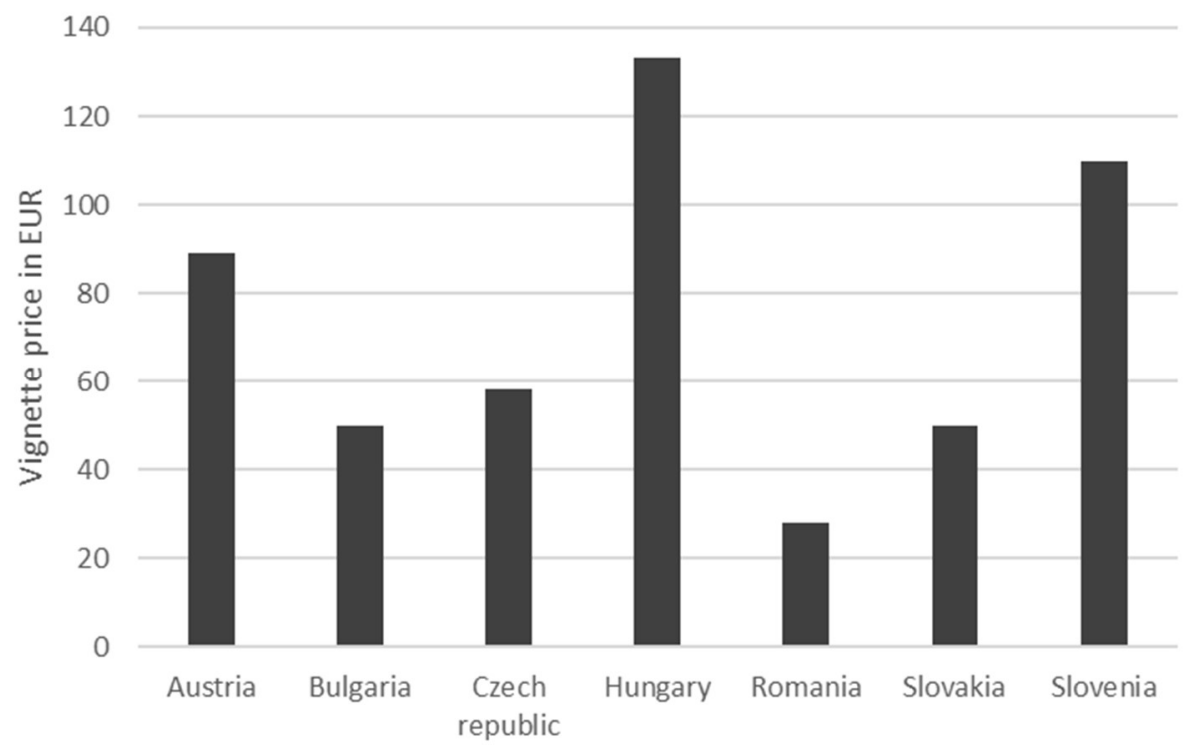

Source: Authors' own work based on Tolls.eu (2019)

The prices of annual vignettes for passenger cars are shown in Figure 1 in all countries except Lithuania, where passenger cars are not subject to this duty. The conversion of Czech and Hungarian currencies to Euro was made using the exchange rate as of 2 January 2019. For the Czech crown, this is 25.75 EUR/CZK, for the Hungarian forint it is 322.35 EUR/HUF (Kurzy.Cz, 2019). The prices in other countries are listed in Euro. The lowest price of a vignette is in Romania, 28 EUR. The highest price is in Hungary, amounting to 133.3 EUR. The Czech Republic has the annual vignette rate similar to Bulgaria and Slovakia.

In view of the currently discussed environmental impacts of transport and the related efforts to include environmental elements to the design of charges levied on the operation of motor vehicles, it is only Lithuania that has introduced such element for vehicles of up to $3.5 \mathrm{t}$ (in the form of factoring the EURO standard applicable to the vehicle), and it only applies to buses and coaches of M2 category, heavy duty vehicles and their N1 category combinations and special vehicles in N1 and M2 categories. None of the EU countries takes into account the important EURO standard relevant for the vehicle, nor any other environmental aspect (ACEA, 2019).

\section{Vignette Model in the Czech Republic}

The model of a new system of time-based pricing using vignettes has been inspired by systems applied in Slovenia, Austria, and Hungary, where the rates differ according to individual categories of vehicles of up to $3.5 \mathrm{t}$, including motorcycles. Motorcycles are currently allowed to drive free of charge on roads and motorways 
in the Czech Republic. The reason for including motorcycles is that motorcycles participate in the traffic and thus the infrastructure wear and burden is similar to passenger cars and N1 light commercial vehicles. That is why the proposed system of pricing includes motorcycles. The determination of the "motorway fee" will differentiate among the categories of included vehicles. Its rates will depend on the degree of the supposed impact of the given category on the transport infrastructure. As mentioned by SFDI (2011), two wheels wear down the infrastructure much less that four wheels of passenger and light commercial vehicles. Moreover, light commercial vehicles carry heavier load than passenger cars and have larger impact on the infrastructure.

SFDI (2011) also mentions that fees for motorcycles should have been imposed as early as in 1995, when this form of time-based fee was introduced. The fact is that there were much fewer motorcycles riding Czech roads and motorways at that time. The situation is different nowadays, as the number of motorcycles registered and operated in the Czech Republic has been rapidly growing. According to the Car Importers Association (SDA), the number of newly registered motorcycles increased by $64.3 \%$ from 2004 to 2018 (SDA, 2019). SFDI (2011) mentions that the number of traffic accidents caused by motorcycles has increased, too. Interventions and liquidation of such accidents are costly, and therefore, such costs can be settled from funds obtained from the sale of vignettes for motorcycles. As mentioned below, accidents where motorcycles are involved are often very serious and require deployment of a large number of rescue units. This fact is evidenced by statistics of accidents, which show that the indicators of accident gravity were the worst for motorcycles in the years 2007 to 2018 (PČR, 2019).

Table 3 Vehicle Numbers on Charged Roads for Selected Vehicle Categories in 2016

\begin{tabular}{lcccc}
\hline & LCV & $\begin{array}{c}\text { Passenger } \\
\text { vehicles }\end{array}$ & Motorcycles & Total \\
\hline \hline $\begin{array}{l}\text { Vehicle numbers in } \\
\text { pieces }\end{array}$ & 604327 & 5496938 & 19950 & 6121215 \\
\hline Share in \% & 9.8 & 89.8 & 0.4 & 100 \\
\hline
\end{tabular}

Source: ŘSD ČR (2016), authors' own calculation form V2_CSD2016.xlsx

Table 3 shows that the share of motorcycles in the total number of vehicles is relatively low compared to passenger cars and LCVs (light commercial vehicles). The data are from 2016, the year of the last national traffic census. Another survey will be conducted in 2021 (data are collected on a five-year basis). The model designed as a result of the present research uses the data from 2016 as the latest source of information on number of vehicles. Therefore, the proposed model relates to the year 2016 . 
As mentioned above, the system of electronic vignettes will be introduced in the Czech Republic in 2021, whereas the rates should remain the same as under the present legal regulation (MD ČR, 2019). However, the prepared amendment to Act No. 13/1997 Coll., Road Act, proposes the increase in the maximum price of annual vignette from $1500 \mathrm{CZK}$ to $2000 \mathrm{CZK}$. The Czech Ministry of Transport is therefore preparing for the increase in rates in order to avoid another amendment in the near future. Nevertheless, in February 2019, the Czech government approved the introduction of electronic vignettes with the amount of CZK 1500 CZK for the annual vignette (MD ČR, 2019).

The present design of the new system of vignettes will be based not only on systems applied in Slovenia, Austria, and Hungary, but also on the assumption that the government will reconsider its current view and the annual price will increase from $1500 \mathrm{CZK}$ to $2000 \mathrm{CZK}$, as contemplated in the prepared amendment. Another assumption in designing the new model is that the total receipts from vignettes will not exceed the present receipts by more than $5 \%$. This assumption has been included due to the frequently mentioned efforts of the Czech Ministry of Finance not to increase current taxes and charges levied in the Czech Republic. The design of the model is also based on the fact that the vignette prices should reflect the degree of the infrastructure wear in connection with the vehicle category. For this reason, the currently applied annual price of $1500 \mathrm{CZK}$ will be assigned to the category of passenger cars whose counts on charged roads predominates; see Table 3. Thus, the largest part of entities paying this fee will not be affected by the increase in its price. In the proposed amendment to Act No. 13/1997 Coll., the maximum price of the annual vignette in the amount of $2000 \mathrm{CZK}$ is assigned to the category of light commercial vehicles due to the fact that this type of vehicles is the worst burden for roads of all the categories charged. The price of a vignette for motorcycles is determined with the help of a ratio derived from the determined prices of vignettes for passenger cars and light commercial vehicles. The vignette price is calculated as follows: Because the vignette for LCVs is $500 \mathrm{CZK}$ more expensive than for passenger cars, the price for passenger cars is $500 \mathrm{CZK}$ higher than for motorcycles. The result of such calculation is that the prices of vignettes for passenger cars are $50 \%$ higher than for motorcycles, and vignettes for LCVs are by $100 \%$ more expensive than for motorcycles. The distribution of annual vignette prices thus corresponds to the assumption on reflecting the degree of transport infrastructure wear by the given category of vehicles to which the timebased fee applies.

At present, the price of the monthly vignette equals to $29.3 \%$ of its annual value and the 10 -day vignette costs $20.7 \%$ of its annual value. These ratios have been maintained in the determination of new prices, as shown in Table 4. 
Table 4 Vignette Prices According to the New Model by Vehicle Categories

\begin{tabular}{lccc}
\hline & $\begin{array}{c}\text { 10 days } \\
\text { (in CZK) }\end{array}$ & $\begin{array}{c}\text { 1 month } \\
\text { (in CZK) }\end{array}$ & $\begin{array}{c}\text { 1 year } \\
\text { (in CZK) }\end{array}$ \\
\hline \hline Motorcycles & 207 & 293 & 1000 \\
\hline Passenger vehicles & 310 & 440 & 1500 \\
\hline Light commercial vehicles & 414 & 586 & 2000 \\
\hline
\end{tabular}

Source: Authors' own calculation

It follows from Table 4 that there is no change in the case of passenger vehicles compared to the current state. In the new category of motorcycles, the prices have been determined by the above method, which respects the present ratios of vignette prices depending on the period of validity. For instance, the 10-day vignette costs 207 CZK, the monthly vignette 293 CZK, and the one-year vignette $1000 \mathrm{CZK}$. For the category of LCVs, the price of annual vignette has increased by $33.33 \%$ compared with the current situation. The higher rates for this category have been determined in accordance with the initial assumption and taking into account the prepared amendment of Act No. 13/1997 Coll., Road Act. The proposed model envisages the exemption of environmentally friendly vehicles (electric and hydrogen-powered vehicles) from the payment of fees on roads that are subject to charges. The support for such vehicles is based on the National Action Plan for Clean Mobility (MPO, 2015); such vehicles do not pollute the environment with harmful emissions unlike conventional petrol or diesel vehicles.

Table 5 lists the receipts of the State Fund of Transport Infrastructure from vignettes in the Czech Republic in 2016. The total income from the sale of vignettes reached the amount of 4757.96 million CZK in 2016.

Table 5 Receipts from the System of Vignettes in 2016

\begin{tabular}{cccc}
\hline Vignette type & $\begin{array}{c}\text { Number of vignettes sold } \\
\text { (in pcs) }\end{array}$ & $\begin{array}{c}\text { Rate } \\
\text { (in CZK) }\end{array}$ & $\begin{array}{c}\text { Receipts } \\
\text { (in CZK) }\end{array}$ \\
\hline \hline 1 year & 2315432 & 1500 & 3473148000 \\
\hline 1 month & 602448 & 440 & 265077120 \\
\hline 10 days & 3289472 & 310 & 1019736320 \\
\hline Total & $\mathbf{6 2 0 7 3 5 2}$ & - & $\mathbf{4 7 5 7 9 6 1 4 4 0}$ \\
\hline
\end{tabular}

Source: SFDI (2016)

The receipts from the sale of vignettes according to the proposed model for the individual categories of vehicles is as follows. The numbers of vignettes sold in a 
category have been determined from the total number of vignettes sold, multiplied by the number of vehicles in the percentages for the vehicle categories (see Table 3 ), rounded up to whole pieces. The resulting numbers of vignettes sold are multiplied by the vignette price calculated in Table 4 for the individual periods of the vignette validity.

Table 6 Receipts from the New Model of Vignettes in 2016

\begin{tabular}{|c|c|c|c|c|c|}
\hline $\begin{array}{c}\text { Vignette } \\
\text { type }\end{array}$ & $\begin{array}{l}\text { Vehicle } \\
\text { category }\end{array}$ & $\begin{array}{c}\text { Share in } \\
\%\end{array}$ & $\begin{array}{c}\text { Number of } \\
\text { vignettes } \\
\text { sold } \\
\text { (in pcs) }\end{array}$ & $\begin{array}{c}\text { Price } \\
\text { (in CZK) }\end{array}$ & $\begin{array}{l}\text { Receipts } \\
\text { (in CZK) }\end{array}$ \\
\hline \multirow{3}{*}{1 year } & Motorcycles & 0.4 & 9262 & 1000 & 9262000 \\
\hline & $\begin{array}{c}\text { Passenger } \\
\text { vehicles }\end{array}$ & 89.8 & 2079258 & 1500 & 3118887000 \\
\hline & LCV & 9.8 & 226912 & 2000 & 453824000 \\
\hline \multirow{3}{*}{1 month } & Motorcycles & 0.4 & 2410 & 293 & 706130 \\
\hline & $\begin{array}{c}\text { Passenger } \\
\text { vehicles }\end{array}$ & 89.8 & 540998 & 440 & 238039120 \\
\hline & LCV & 9.8 & 59040 & 586 & 34597440 \\
\hline \multirow{3}{*}{10 days } & Motorcycles & 0.4 & 13158 & 207 & 2723706 \\
\hline & $\begin{array}{c}\text { Passenger } \\
\text { vehicles }\end{array}$ & 89.8 & 2953946 & 310 & 915723260 \\
\hline & LCV & 9.8 & 322368 & 414 & 133460352 \\
\hline Total & & & 6207352 & & 4907223008 \\
\hline
\end{tabular}

Source: Authors' own calculation

Table 6 lists the numbers of vignettes sold and determines the receipts from each included category of vehicles that are obliged to have a vignette when driving on charged sections of roads in the proposed model. The receipts according to the new model are $3.14 \%$ higher than those based on the current system (using data from the year 2016). In absolute terms, this is the amount of 149.262 million CZK.

\section{Conclusions}

At present, the Czech Republic applies vignettes for vehicles of up to $3.5 \mathrm{t}$, similarly to other seven countries of the European Union: Bulgaria, Lithuania, Hungary, Austria, Romania, Slovakia, and Slovenia. Vehicles with weight exceeding $3.5 \mathrm{t}$ are subject to charges based on traffic performance, which applies in another $22 \mathrm{EU}$ countries (all member states except for Bulgaria, Finland, Lithuania, Cyprus, Malta, and Romania). Vignettes in the Czech Republic are compulsory for all vehicles with at least four wheels and the maximum permitted weight of up to $3.5 \mathrm{t}$ driving along 
priced roads. The current system of vignettes does not differentiate among vehicles with weight below $3.5 \mathrm{t}$ and the vignette price is uniform amounting to $1500 \mathrm{CZK}$.

The goal of this contribution was, on the basis of pre-defined assumptions, to create a model of time-based fees paid for the operation of various categories of vehicles of up to $3.5 \mathrm{t}$. The results stated in the text may be summarized into the following conclusions regarding the designed model of vignettes in the Czech Republic. A substantial change was made in the system of time-based fees: the single category of vehicles below $3.5 \mathrm{t}$ was divided into the groups of passenger vehicles and light commercial vehicles. Another group - motorcycles, which have not been subject to road charges up to now, was added. This fact reflects the first assumption defined before the design of the new model. The prices of annual, monthly and 10-day vignettes were calculated for each category of the vehicles. Vignette prices were determined depending on another assumption of the proposed model, i.e. reflecting the degree of transport infrastructure wear attributable to the operation of a given type of vehicles. Another pre-defined assumption was that the total receipts from the sale of vignettes will not exceed $5 \%$. This assumption was also met and the amount of total receipts based on the model year 2016 was $3.14 \%$ higher. The data from 2016 were used because of the availability of comprehensive information enabling the design of a time-based fee model. The proposed model also assumes that the range of exemptions under Section 20a Act No. 13/1997 Coll., will be expanded to include "green" vehicles, i.e. electric and hydrogen-powered vehicles, thereby contributing to the fulfillment of goals set out in the National Action Plan for Clean Mobility.

The designed model of a time-based fee in the Czech Republic is definitely a challenge that, if put to practice, would effectively address the existing imperfections of the current system of pricing the operation of road motor vehicles in the Czech Republic.

\section{Acknowledgments}

This paper was supported by the Internal Grant agency PEF MENDELU [PEF_TP_2020007].

\section{References}

ACEA. (2019). Tax Guide 2019. Retrieved from: https://www.acea.be/uploads/ news_documents/ACEA_Tax_Guide_2019.pdf.

Andrlík, B. (2012). Taxation of passenger motor vehicles with environmental aspect. Acta Universitatis Agriculturae et Silviculturae Mendelianae Brunensis, 60(7), pp. 9-18. 
Andrlík, B. (2014). Carbon dioxide emissions as an indicator of reduction of negative externalities related to road motor vehicle operation. Acta Universitatis Agriculturae et Silviculturae Mendelianae Brunensis, 62(4), pp. 613-621.

Andrlík, B., Mísařová, P. and Vrtalová, J. (2014). Preparedness of the Czech Republic for taxation of road motor vehicles based on CO2. Procedia Economics and Finance, 12, pp. 10-19.

Andrlík, B. and Ptáčková Mísařová, P. (2018). Environmentální prvky časového a výkonového zpoplatnění provozu silničních motorových vozidel. In: Trendy $v$ podnikání 2018. Plzeň: Západočeská univerzita. Retrieved from: https://drive.google.com/file/d/1JZt2x5Wd7Wp2heon-GK8xroT9zCZ1pxo/view? usp=sharing

Andrlík, B. and Péteriová, J. (2019). Zdanenia motorových vozidiel na Slovensku so zameraním na ekologické prvky. Acta Sting, pp. 6-26. ISSN 1805-6873. Retreived from: https://www.sting.cz/acta/acta2_2019_web.pdf.

Andrlík, B. and Zborovská, L. (2019). Toll System Charging Negative Externalities: Case of The Czech Republic. In: Proceedings of International Scientific Conference Economic and Social Policy: Economic and Social Challenges for European Economy. Havířov: Vysoká škola PRIGO, pp. 1-16. ISBN 978-80-87291-25-2. Dostupné z: http://www.narodacek.cz/conference-proceedings-2019/.

Cnossen, S. (2005). Theory and Practice of Excise Taxation: Smoking, Drinking, Gambling, Polutiong and Driving. 1st ed. Oxford: Oxford University Press.

Communication from the Commission $\operatorname{COM}(2012)$ 199. (2012). COMMUNICATION FROM THE COMMISSION COM (2012) 199 on the application of national road infrastructure charges levied on light private vehicles. Retrieved from: https://eurlex.europa.eu/legal-content/EN/TXT/?qid=1559300280663\&uri=CELEX\%3A52012 DC0199.

Directive 2006/38/EC of the European Parliament and of the Council. (2006). Directive 2006/38/EC of the European Parliament and of the Council of 17 May 2006 amending Directive 1999/62/EC on the charging of heavy goods vehicles for the use of certain infrastructures. Retrieved from: https://eur-lex.europa.eu/legalcontent/EN/ALL/?uri=CELEX\%3A32006L0038.

KURZY.CZ. (2019). Převod měn-Převodník měn online. Retrieved from: https://www. kurzy.cz/kurzymen/kurzy.asp?a $=$ X\&mena1 $=$ CZK\&mena2 $=$ EUR\&C $=15$ 00\&d=02.01.2019\&convert $=P \% F 8$ eve $\% E F+m \% E C n u$.

MD ČR. (2019). Vláda podpořila zavedení elektronických dálničních známek, zdražovat se nebude. Retrieved from: https://www.mdcr.cz/Media/Media-atiskove-zpravy/Vlada-podporila-zavedeni-elektronickych-

dalnicnich?returl=/Media/Media-a-tiskove-zpravy. 
MPO. (2015). Národní akční plán čisté mobility. Retrieved from: https://www.mpo.cz/cz/prumysl/zpracovatelsky-prumysl/automobilovyprumysl/narodni-akcni-plan-ciste-mobility--167456/.

Nařízení č. 240/2014 Sb., o výši časových poplatků, sazeb mýtného, slevy na mýtném a o postupu při uplatnění slevy na mýtném. (2019). Retrieved from: https://www.zakonyprolidi.cz/cs/2014-240/zneni-20150101\#p4.

Opinion $\operatorname{COM}(2008)$ 435. (2008). Opinion of the European Economic and Social Committee on the Communication from the Commission to the European Parliament, the Council, the European Economic and Social Committee and the Committee of the Regions - Strategy for the internalisation of external costs $\operatorname{COM}(2008)$ 435. Retrieved April 25, 2019, from: https://eur-lex.europa.eu/legalcontent/EN/TXT/?qid=1559300555259\&uri=CELEX\%3A52009AE1195.

PČR. (2019). Statistika nehodovosti. Retrieved from: https://www.policie.cz/CLANEK/STATISTIKA-NEHODOVOSTI-900835.ASPX.

ŘSD ČR. (2016). Celostátní sčítání dopravy 2016. Retrieved from: https://www.rsd.cz/wps/portal/web/Silnice-a-dalnice/Scitani-dopravy.

SDA. (2019). Registrace nových vozidel kategorie L v ČR 3/2019. Retrieved from: http://portal.sda-

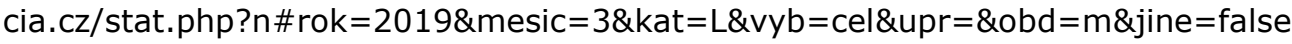
\&lang $=$ CZ\&str $=$ nova.

SFDI. (2011). Dálniční poplatky pro motorky - letos ještě ne. Retrieved from: https://www.rozhlas.cz/zelenavlna/motorkari/_zprava/dalnicni-poplatky-promotorky-letos-jeste-ne--941639.

SFDI. (2016). Závěrečná zpráva k hospodářským výsledkům dálničních kupónů emise 2016. Retrieved from: https://www.sfdi.cz/dalnicni-kupony/zaverecnezpravy/.

SFDI. (2018). Vývoj cen dálničních kuponů. Retrieved from: https://www.sfdi.cz/dalnicni-kupony/dalnicni-kupony-2018/vyvoj-cen-dalnicnichkuponu/.

TOLLS.EU. (2019). Dálniční známky a poplatky v Evropě 2019. Retrieved from: https://www.tolls.eu/cs/.

Treaty on the Functioning of the European Union. (2012). Treaty on European Union and the Treaty on the Functioning of the European Union. Retrieved from: https://eur-lex.europa.eu/legal-

content/EN/TXT/ ?qid=1559119014253\&uri=CELEX\%3A12012E\%2FTXT.

Vyhláška č. 386/2017 Sb. (2017). Vyhláška č. 386/2017 Sb., ze dne 21. listopadu 2017, kterou se mění vyhláška č. 306/2015 Sb., o užívání pozemních komunikací zpoplatněných časovým poplatkem, ve znění vyhlášky č. 383/2016 Sb. o výši časových poplatků, sazeb mýtného, slevy na mýtném a o postupu při uplatnění slevy na mýtném. Retrieved from: https://www.zakonyprolidi.cz/cs/2017-386. 
White Paper. (2011). Roadmap to a Single European Transport Area - Towards a competitive and resource efficient transport system. Retrieved from: https://eurlex.europa.eu/legal-content/EN/TXT/HTML/?uri=CELEX:52011DC0144\&from=EN.

Zákon č. 134/1994 Sb., (1994). Zákon č. 134/1994 Sb., kterým se mění a doplňuje zákon č. 135/1961 Sb., o pozemních komunikacích (silniční zákon), ve znění pozdějších předpisů, a zákon České národní rady č. 200/1990 Sb., o přestupcích, ve znění pozdějších předpisů. Retrieved from: https://www.zakonyprolidi.cz/cs/1994-134.

Zákon č. 13/1997 Sb., o pozemních komunikacích. (1997). Zákon č. 13/1997 Sb., o pozemních komunikacích. Retrieved from: https://www.zakonyprolidi.cz/cs/1997-13. 